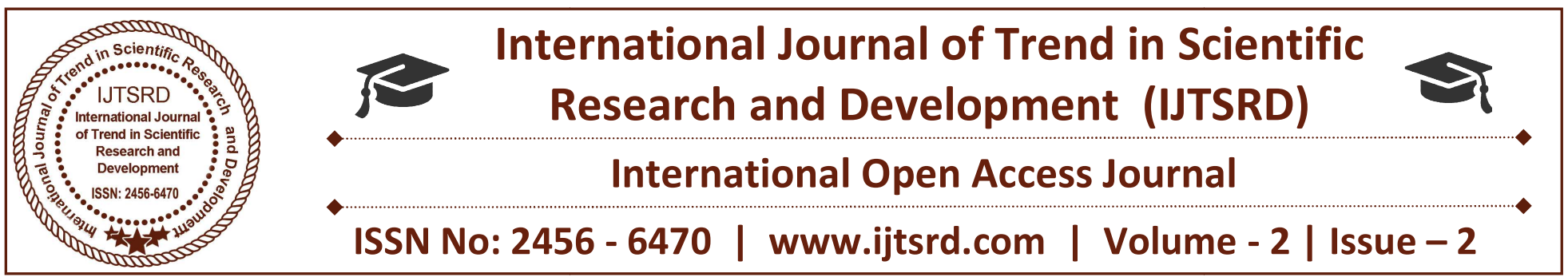

\title{
Psychological Impact of GST on Small Business
}

\author{
Abbul Hasan Khan \\ Associate Professor, Monad University, Uttar Pradesh, India
}

\begin{abstract}
\end{abstract}
India is very unique by birth it is known for good hospitality and eco friendly business environment for small and big player equally by RBI survey almost nine million SMEs are existed in India. what you see and hear both are not correct some time such situation emerge than the role of SMEs come in picture let me clear it by giving estimation by researcher that Number of SMEs are behind one big company. That is why contribution of this sector is directly $7 \%$ and indirectly $30 \%$ in economy .But since implementation of GST raises several questions on very existence of the sector because $70 \%$ are not in threshold limit of GST so these are not in range of getting input tax credit. Under the previous tax regime, if your business had operations across many states, you would have to register for sale tax/ VAT with each state's sales tax department in order to do business activities .The reason that every state had different tax laws complicated the entire process, and business owners had to pay many procedural charges for VAT registration and uncontrolled chain of cascading started. Under GST, the registration is centralized and the rules are uniform for all the states across the country.

Keywords: GST, GSTIN, GST No. SME Input tax credit

\section{Introduction:}

Indian society is mix of everything maybe culture religion and caste so the business. Here small business are mostly family driven and big business has the same conditions that is why son of cobbler is cobbler and son of businessman is businessman by analysis of The economic time only 10 families are bagging more than $70 \%$ business and alone $2 \%$ population share $58 \%$ asset of the country. Despite being so complicated and uneven distribution of wealth and business India is known for land of startup and SMEs. But all small business is performing their business in very simple way in modern language relay on bricks and mortar. So the fair of implementing GST uniformly to every business houses small or big both. Left most of small businessman goes without sleep in nights. In my study I talked to 100 odd small businessmen of Crossing republic GZB and Greater Noida West (UP) and two senior persons of a company dealing with billing software they almost meet to 100 of people every day. And got very useful information which is integral part of my study

GSTN: This software is back bone of GST without this software GST could not fully implemented. Combined Stake of Central and State Government in GSTN is $49 \%$ the remaining $51 \%$ stake is divided among five financial institutions-

LIC Housing Finance with $11 \%$ stake and ICICI Bank, HDFC, HDFC Bank and NSE Strategic Investment Corporation Ltd with 10\% stake each.

\section{Literature Review:}

(Dr Arun). There are much apprehension relating to proposed GST regime regarding the growth in Indian Economy and its effects thereof. As we know in India economy, destination based taxation requires high compliance cost and efficient administration. This paper examines the impact of goods and services tax (GST) on economic growth India. Only a registered person can charge and collect GST on the taxable supplies of goods and services made by him. GST is 
charged on the value or selling price of the products. The amount of GST incurred on input (input tax) can be deducted from the amount of GST charged (output tax) by the registered person. This way GST is easy and transparent indirect tax. .This is regressive tax risks puller to Ambani both pay equally

\section{Historic moment in tax reform}

Taxes were levied at each stage separately at various rates under the Indian Taxation System. But the new GST (Goods and Services Tax) has been established as the unified indirect tax on goods and services. The GST was launched on midnight 1 July, 2017 at a special event in the presence of President Pranab Mukherjee and Prime Minister Narendra Modi. From July 1, 2017, the GST being levied in India is in five categories, at the rates of zero percent, $5 \%, 12 \%, 18 \%$ and $28 \%$ per annum. Latest update by the Finance Ministry: Commodities of daily use like washing powder, aftershave cream, detergent, chocolate are likely to get cheaper as the GST Council has decided to keep only 50 items in the top tax bracket of 28 per cent. The decision was taken at a 'close-door' meeting of GST Council in Guwahati on Friday. Gifts up to a value of Rs 50,000/- per year by an employer to his employee are outside the ambit of GST. Gifts of more than Rs 50,000/- made without consideration are subject to GST, when made in course or furtherance of business

\section{Data interpretations}

\begin{tabular}{|l|l|l|l|}
\hline $\begin{array}{l}\text { Category of } \\
\text { Business }\end{array}$ & Response & Numbers & $\begin{array}{l}\text { Awareness level } \\
\text { in \% }\end{array}$ \\
\hline Confectionary & Positive & 20 & $60 \%$ \\
\hline Restaurant & Negative & 10 & $40 \%$ \\
\hline Furniture & Positive & 10 & $70 \%$ \\
\hline Builders & Negative & 20 & $30 \%$ \\
\hline RO distributor & Negative & 20 & $50 \%$ \\
\hline Professional & positive & 10 & $20 \%$ \\
\hline Grocery & Positive & 10 & $90 \%$ \\
\hline
\end{tabular}

(a)

\section{Problems with GST}

They are not used to maintaining accounting books

$>$ They are confused about filling of returns

$>$ They also worried about penalties and fine on the base of non compliance of GST

$>$ How can they turn traditional business into computer operated modern one?

\section{Benefits of GST}

$>$ Buyers can get input tax credit immediately

$>$ Attract more business

Reduce chances of audit by the tax authorities.

A low GST rating will attract higher scrutiny from the department.

Enjoy better reputation

Reduction of tax burden

$>$ Many taxes to single tax

$>$ Removal of cascading

> Simplification of tax return 


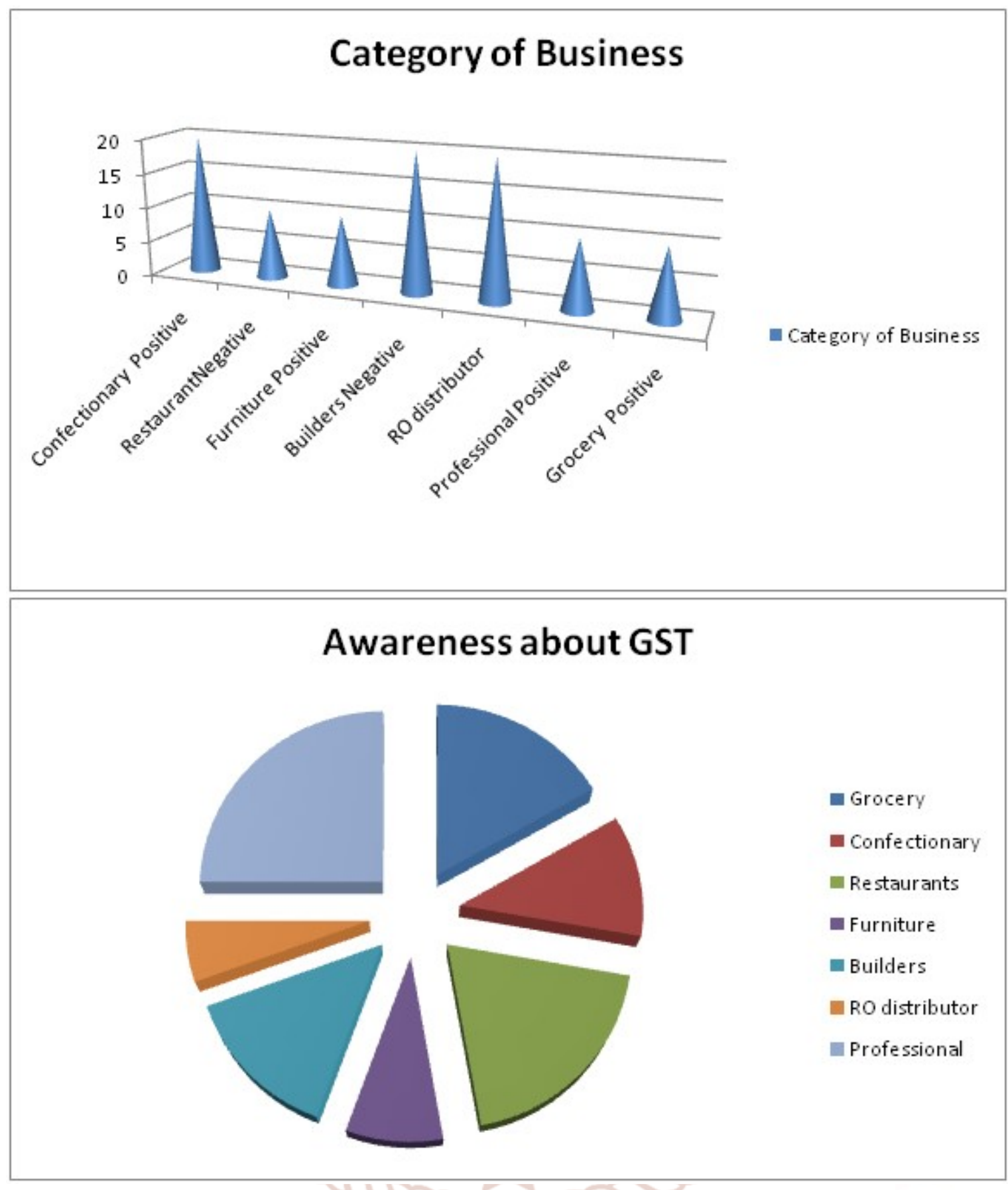

\section{Conclusion:}

GST is biggest reform no doubt about it but my study shows that people are not ready for this radical change and a lot of confusion is built in the mind and heart of common people. Despite being noble intention and greater importance given by world bodies things cannot turn better on the ground. And continuous meetings of GST council and in every meeting the results are less or more as per expectations if there is any election period is near so council reacts differently than routine one. GST is more than just a tax change. It is also a 'behavior change' and its successful implementation will depend on how well we as a nation adapt to the new requirements of doing business. Post the initial teething troubles, it is expected that GST will bring in much good for all sectors and all sections of society

\section{REFERENCES}

1. A Comprehensive Guide Book on GST India by Clear Tax

2. Union Budget speech of Arun Jaitly

3. The economic times (1 July 2017 to 1january 2018) 
4. KHAN A.H (International Journal of Trend in Scientific Research and Development (IJTSRD) International Open Access Journal) Indian Banking Sector and Micro Finance

5. http://www.ijtsrd.com/papers/ijtsrd5898.pdf

6. http://www.ijtsrd.com/papers/ijtsrd4596.pdf

\section{Annexure I}

I am asking about GST and I am independent researcher your views are important for academic purposes nothing to do with anything regarding tax authorities and your personal information not be disclosed

1. What do you think about GST?

2. What impact do you see on your business?

3. Do you know GST remove tax evasions?

4. Do you think it creates transparency and reduce corruption?

5. Do you know threshold limit of GST?

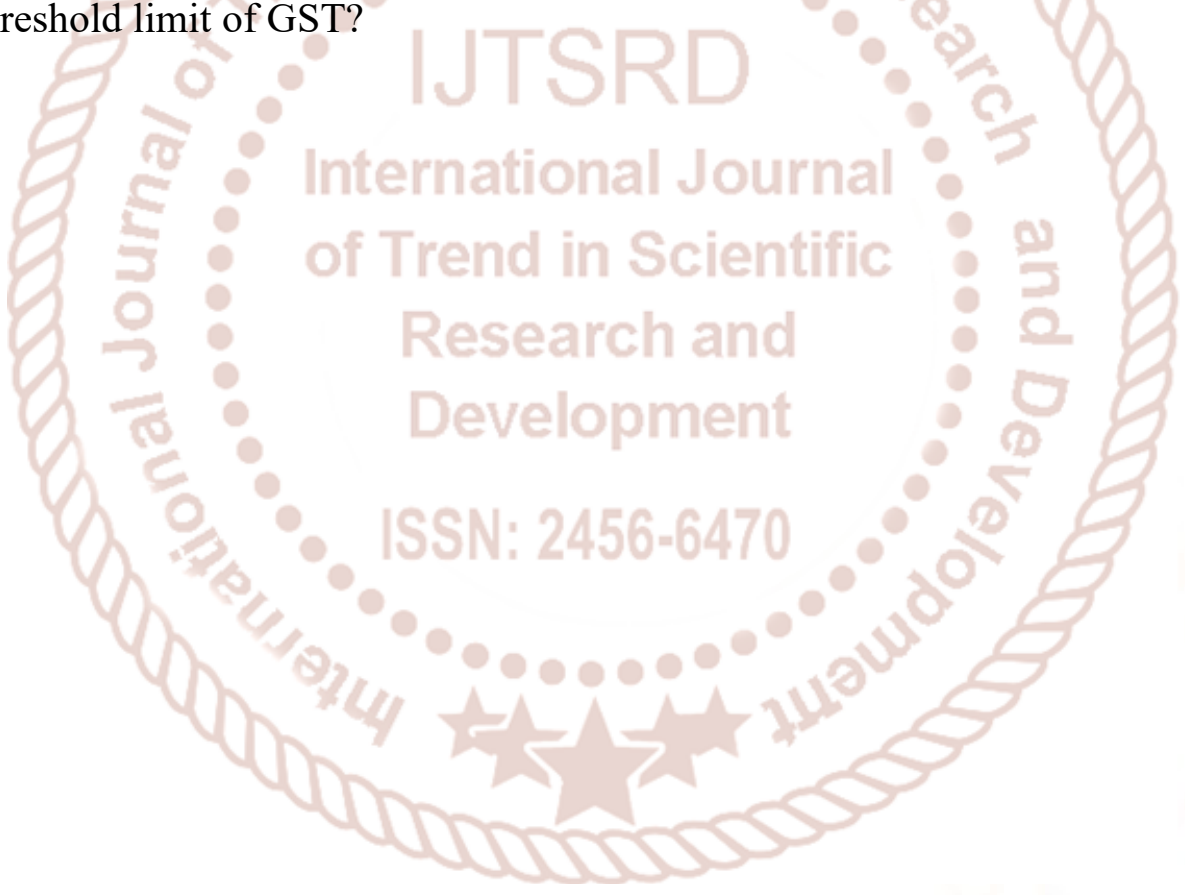

